\title{
Partisipasi Perempuan Desa Karangsari Dalam Mewujudkan Pembangunan Inklusif
}

\author{
Tri Hariyono \\ Swara Nusa Institute Kulonprogo, DIY \\ Email: Trie hariyono@ymail.com
}

\begin{abstract}
Substantially, Law of concerning Village No. 6 of 2014 has the aim of realizing a village government that is professional, efficient, effective, open and accountable. Karangsari village, Kulonprogo DIY in managing village assets provides space for every villager, especially women, vulnerable and marginalized groups to be involved in managing village assets, especially in optimizing sustainable livelihoods. The involvement of women, vulnerable and marginalized groups can be seen through the Village Deliberation Forum (Musdes), they participate in providing input and suggestions related to village development and economic arrangement based on sustainable livelihoods. In addition, women and marginalized groups in villages also bave the same opportunity to utilize assets in three sector areas, namely the agricultural sector, MSMEs, and tourism. More than that, the economic dynamics of village women not only get institutional support, such as organizing groups such as KDDK, KWT, and skills, but they also get support for marketing access that integrates the local village economy into the market for products of micro, small and medium enterprises (UMKM) are wider.
\end{abstract}

Keywords: Inclusive Development; Women; Village Asset Management

\begin{abstract}
Abstrak
Secara substansial, Undang-Undang No 6 tabun 2014 tentang Desa mempunyai tujuan untuke mewujudkan pemerintahan desa yang profesional, efisien, efektif, terbuka dan bertanggung jawab. Desa Karangsari, Kulonprogo DIY dalam pengelolaan aset desa memberikan ruang bagi setiap orang warga desa terutama perempuan, kelompok rentan dan marjinal terlibat dalam pengelolaan aset desa terutama dalam mengoptimalkan penghidupan berkelanjutan. Keterlibatan perempuan, kelompok rentan, dan marjinal ini bisa dilihat melalui Forum Musyawarah Desa (Musdes) mereka berpartisipasi ikut memberikan masukan dan usulan terkait dengan pembangunan desa dan penataan ekonomi berbasis penghidupan berkelanjutan. Di samping itu perempuan dan kelompok marjinal di desa juga memiliki kesempatan yang sama dalam memanfaatkan aset dalam tiga sektor area yaitu sektor pertanian, UMKM, dan Pariwisata. Lebib dari itu, dinamika ekonomi perempuan desa tidak hanya mendapatkan dukungan kelembagaan, seperti pengorganisasian kelompok seperti KDDK, KWT, dan bekal keterampilan, tetapi mereka juga mendapatkan dukungan akses pemasaran yang mengintegrasikan ekonomi lokal desa ke dalam pasar produk usaha mikro, kecil, dan menengah (UMKM) yang lebih luas.
\end{abstract}

Kata Kunci: Pembangunan Inklusif; Perempuan; Tata Kelola Aset Desa 


\section{A. Pengantar}

Pembangunan di Indonesia selama ini masih menfokuskan perhatian pada pertumbuhan yang mengandalkan investasi besar, ${ }^{1}$ namun kurang mengikutsertakan rakyat kecil sebagai subyek dan bagian utama dari pembangunan. Pembangunan sosial masih dipandang sebelah mata dan hanya dianggap sebagai sesuatu yang bersifat residual. Padahal, di negara-negara berkembang lainnya, pembangunan sosial sudah mulai menjadi bagian integral dari pembangunan ekonomi dan kedua elemen ini saling mendukung. ${ }^{2}$ Akibat dari mengabaikan pembangunan sosial ini sering terjadi ekslusi pembangunan pada masyarakat bawah, rakyat miskin mengalami ketertutupan akses serta tertinggal dalam setiap proses pembangunan.

Dalam peta pembangunan, selama ini sering terlena oleh sekian janji bahwa paradigma pertumbuhan sebagaimana disinggung di atas, akan memakmurkan semua anggota masyarakat melalui trickel-down. Namun faktanya pertumbuhan ekonomi tidak serta merta menciptakan lapangan pekerjaan dan menambah lapangan pekerjaan, apalagi menanggulangi kemiskinan. ${ }^{3}$ Paradigma ini menghalalkan penyitaan sebagian hasil pembangunan oleh mereka yang telah mapan dan menyisakan sebagian kecil hasil pembangunan "diteteskan" kepada mayoritas rakyat. Untuk itu, diperlukan paradigma pembangunan baru yang secara adil dan merata melibatkan seluruh masyarakat secara aktif sehingga hasil pembangunan dapat dinikmati oleh seluruh masyarakat. Pelibatan seluruh masyarakat secara aktif tersebut, memunculkan istilah pembangunan inklusif. ${ }^{4}$

\footnotetext{
${ }^{1}$ Bulan Juli 2010, Japan Credit Rating Agency Ltd (JCR), misalnya, memperbaiki peringkat Indonesia hingga mencapai Investment grade (level investasi). Tidak mengherankan, investor portofolio membanjiri pasar keuangan domestik sejak akhir 2010 hingga 2011.

${ }^{2}$ Untuk kajian lebih dalam terkait dengan isu pembangunan sosial di negara berkembang, lihat Riant Nugroho, Kebijakan Sosial untuk Negara Berkembang (Yogyakarta: Pustaka Pelajar, 2014). Soetomo, Masalah Sosial, Pembangunan Sosial dan Kesejabteraan (Yogyakarta: Pustaka Pelajar, 2018).

${ }^{3}$ Mansour Fakih, Runtubnya Teori Pembangunan dan Globalisasi (Yogyakarta: Pustaka Pelajar dan Insist Press, 2001), hlm.70

4 A Prasetyantoko, Sugeng Bahagiyo,dan Setyo Budiantoro, Prolog "Prospek dan Tantangan Pembangunan Inklusi di Indonesia", dalam A Prasetyantoko, Sugeng Bahagiyo,dan Setyo Budiantoro ed. Pembangunan Inklusif: Prospek dan Tantangan Indonesia, (Jakarta: LP3ES dan Prakarsa, 2012), hlm.3
} 
Secara sederhana, pembangunan inklusif bisa dimaknai sebagai pembangunan untuk semua lapisan masyarakat tanpa ada satupun yang ditinggalkan yang hendak meraih kemajuan dan kemakmuran bersama dengan pergulatan kerakyatan, kemartabatan dan kemandirian". ${ }^{5}$ Tema tentang pembangunan inklusif dewasa ini kian menarik perhatian dan dianggap penting, terutama setelah diberlakukan Undang-Undang Nomor 6 Tahun 2014 Tentang Desa (UU Desa). UU Desa ini melahirkan struktur kesempatan yang memungkinkan desa tumbuh berkembang menjadi kuat, maju, mandiri dan demokratis. Kedudukan desa, dengan asas rekognisi dan subsidiaritas, berubah menjadi subyek pembangunan, memiliki kewenangan dan anggaran yang cukup guna mengurus aset desa dalam upaya mengoptimalkan penghidupan berkelanjutan. ${ }^{6}$

Berbicara tentang pengelolaan aset desa terutama dalam mengoptimalkan penghidupan berkelanjutan, seringkali dibatasi hanya urusan laki-laki, sementara perempuan desa dianggap cukup berperan diranah domestik saja, seperti mengurus rumah tangga, mengantarkan makanan ke ladang atau ke sawah, serta mencari air bersih untuk kebutuhan rumah tangga. Akibatnya, keterlibatan perempuan dalam pengelolaan aset untuk kepentingan ekonomi maupun dalam kerangka menemukan penghidupan berkelanjutan tidak banyak diungkap.

Tulisan ini hendak menjawab terkait permasalah dimaksud, yaitu dengan memanfaatkan perspektif sustainable livelihoods, bagaimana perempuan di desa Karangsari, Kulonprogo keluar dari styrotipe dan mulai melibatkan diri dalam pengelolaan aset untuk kepentingan ekonomi maupun terlibat dalam pengelolaan aset desa dan memanfaatkannya dalam konteks pengembangan sumber penghidupan. ${ }^{7}$ Lalu, mengapa perempuan dan desa Karangsari sebagai evidence-

\footnotetext{
${ }^{5}$ Adi Sasono, Menjadi Tuan Di Negeri Sendiri: Pergulatan Kerakyatan, Kemartabatan, dan Kemandirian (Jakarta: Grafindo Books Media, 2013).

6 Sutoro Eko, et.al. Desa Membangun Indonesia (Yogyakarta: FPPD, 2014), hlm.45-46.

7 Sustainable livelihoods atau sumber penghidupan berkelanjutan adalah sebuah konsep yang mengombinasikan antara kemampuan, keadilan, dan keberlanjutan dalam menjaga aset (baik yang terlihat maupun yang tidak terlihat) guna memperoleh kehidupan yang lebih baik dan berkesinambungan. Penghidupan dikatakan memiliki dimensi sustainable atau berlanjut jika mampu bertahan menghadapi berbagai goncangan maupun tekanan. Lihat Chambers, R., \& Conway, G.
} 
Partisipasi Perempuan Desa Karangsari...

based practice?8 Perempuan desa adalah aktor berwajah ganda. Pada satu sisi perempuan desa adalah komponen kelompok warga desa yang miskin dan rentan dipinggirkan secara sosial, ekonomi, dan politik. Tetapi, di sisi lain, perempuan desa merupakan kekuatan utama di desa, terutama dalam hal mengelola dan memanfaatkan aset desa. Penguasaan aset dan adanya akses tentu membutuhkan keberlanjutan. Inilah yang disebut strategi penghidupan. Secara ringkas, strategi penghidupan adalah portofolio penghidupan berkelanjutan seseorang yang bisa ditempuh melalui strategi pertanian, non-pertanian dan/atau melakukan migrasi, bahkan berorganisasi. ${ }^{9}$ Disamping itu, berbekal perspektif penghidupan berkelanjutan, tulisan ini juga ingin memperlihatkan bahwa perempuan desa adalah profil warga aktif yang mampu mencari dan mengoptimalkan aset desa serta mengembangkan penghidupan berkelanjutan untuk keluar dari kesulitan ekonomi. Para perempuan desa ini memilih berorganisasi sebagai salah satu strategi nafkah dalam rangka mengembangkan penghidupan berkelanjutan.

Ada beberapa hal yang menarik sehingga perlu dilakukan penelitan lebih mendalam terkait dengan strategi penghidupan di desa Karangsari ini, pertama, selaian desa Karangsari merupakan desa yang cukup banyak memiliki potensi, baik potensi alam, sosial maupun budaya, juga menjadi desa pertama di kabupaten Kulonprogo yang dinobatkan sebagai desa teknologi informasi dimana setiap aktivitas dan potensi desa bisa diakses melalui jaringan internet. ${ }^{10}$ Kedua, Pemerintah desa Karangsari dalam pengelolaan aset desa serta penganggaran pembangunan desa sudah mulai melibatkan masyarakat terutama perwakilan dari kelompok perempuan. Melalui forum Musyawarah Desa (Musdes) mereka berpartisipasi ikut memberikan masukan dan usulan terkait dengan pembangunan

Sustainable rural livelihoods: practical concepts for the 21st century. Institute of Development Studies (UK), 1992.

8 Praktek-praktek pekerjaan sosial dengan memadukan antara teori dan praktek dalam berbagai studi kasus evidence-based practice bisa di lihat tulisannya Carol L. Langer dan Cynthia A. Lietz, Applying Theory to Generalist Social Work Practice: A Case Study Approach (Canada: Wiley, 2015).

9 Sutoro Eko, dkk, Mutiara Perubahan: Inovasi dan Emansipasi Desa dari Indonesia Timur, (Yogyakarta: IRE dan ACCESS Phase II, 2013), hlm.5

${ }^{10}$ Laporan Assesment, "Problem-Problem Tata Kelola Aset Desa yang Inklusif dan Memihak Kaum Rentan di Desa Karangsari Kulonprogo", (Kulonprogo: Swara Nusa Institute, 2017), hlm.2 
desa dan penataan ekonomi berbasis penghidupan berkelanjutan. Ketiga, hadirnya Non Goverment Organization (NGO) seperti Swara Nusa Institute ${ }^{11}$ turut memberikan kontribusi positif baik untuk Pemerintah Desa maupun untuk pengembangan masyarakat Karangsari.

\section{B. Desa Karangsari dan Pengelolaan Aset}

Desa Karangsari di Kecamatan Pengasih Kabupaten Kulonprogo semula merupakan gabungan dari 3 (tiga) Kelurahan, yaitu Kelurahan Josutan, Kelurahan Kopat dan Kelurahan Kedungtangkil pada Tahun 1947. Desa dengan luas 1.169,91 Hektare ini memiliki topografi yang berbukit-bukit dengan ketinggian rata-rata $20 \mathrm{~m}$ di atas permukaan laut. ${ }^{12}$ Jumlah penduduk per tahun 2016 sebanyak 10,687 jiwa atau 2.769 KK yang tersebar di dua belas pedukuhan yaitu Padukuhan Kopat, Padukuhan Cekelan, Padukuhan Dukuh, Padukuhan Josutan, Padukuhan Sendang, Padukuhan Gunung Pentul, Padukuhan Suruhan, Padukuhan Ringinardi, Padukuhan Blumbang, Padukuhan Kedung Tangkil, dan Padukuhan Kamal.

Pada dasarnya kehidupan warga Karangsari masih bercorak agraris, hal itu dapat dilihat dari pola kehidupan masyarakat petani yang dipengaruhi oleh kebudayaan dan keagamaan. ${ }^{13}$ Mayoritas masyarakat Karangsari bermata pencaharian sebagai petani baik petani pemilik lahan maupun buruh tani. Mereka menanam tanaman pangan seperti padi, jagung, macam-macam ubi, cabai dan sebagainya. Selain itu lahan pekarangan warga banyak tumbuh pohon kelapa sebagai pemasukan bulanan, belum banyak warga yang memanfaatkan pekarangan yang dimiliki untuk menaman buah-buahan (seperti mangga, rambutan), hanya ada pohon pisang dan belum dikembangankan menjadi pertanian produktif, hanya

11 Swara Nusa Institute (SNI) merupakan sebuah organisasi masyarakat sipil (CSO) yang konsern dalam kerja-kerja pemberdayaan komunitas, pengorganisasiaan dan advokasi kebijakan bagi kelompok rentan dan marjinal di wilayah Propinsi DIY dan Jawa Tengah. Isu-isu seputar inklusi sosial, demokrasi lokal, partisipasi politik warga terutama kelompok rentan dan marjinal dalam proses pembangunan desa dan kabupaten masih menjadi perhatian utama dari kerja-kerja Swara Nusa Institute yang dilakukan melalui berbagai kegiatan antara lain; (1) riset-advokasi kebijakan;(2) peningkatan kapasitas kelompok rentan dan marjinal; (3) Publikasi dan Seminar.

12 Rencana Pembangunan Jangka Menengah Desa (RPJMDesa) 2019-2024, hlm.5

13 Nur Khoiriyah, "Pandangan Sosial Ekonomi dan Keagamaan Masyarakat Petani Di Jawa", dalam Islamic Review: Jurnal Riset dan Kajian Keislaman, Vol. VI No.2 Tahun 2017, hlm. 233 
Partisipasi Perempuan Desa Karangsari...

sekedar mengisi lahan kosong sesekali dapat dijual untuk membantu memenuhi kebutuhan sehari-hari. Tidak ada data pasti tentang berapa luas kepemilikan lahan secara riil di desa. Namun kita dapat melihat komposisi tenaga kerja di sektor pertanian sebanyak 1.504 orang warga yang merupakan petani, sementara 48 orang sebagai buruh tani. Kondisi ini menunjukkan betapa sektor pertanian menjadi sebagian besar warga untuk mencari penghidupan. ${ }^{14}$

Kondisi alam yang berbukit-bukit dan bebatuan serta lahan pertanian sempit dan kurang produktif ini akhirnya banyak warga Karangsari mencoba beralih profesi sebagai buruh harian lepas, komposisinya sekitar 971 orang warga, baik menjadi buruh bangunan maupun pekerjaan lainnya disekitar desa maupun keluar dari kecamatan. Kondisi tersebut mengonfirmasi corak kemiskinan di desa yang disebabkan oleh ketiadaan kepemilikan aset produktif, yakni lahan pertanian sehingga mereka terpaksa beralih profesi menjadi buruh harian lepas. Disamping beralih menjadi buruh harian lepas, warga desa sebagian lainnya juga beralih ke profesi sebagai wiraswasta, komposisi sebanyak 1.956 orang warga, namun dalam skala memiliki usaha peternakan, kerajinan, warung dan toko kelontong yang menyediakan kebutuhan sehari-hari. ${ }^{15}$

Desa Karangsari merupakan desa yang cukup banyak memiliki potensi, baik potensi alam, sosial maupun budaya. Untuk potensi alam, ada dua tempat wisata yang dijadikan rintisan wisata yaitu terowongan gua batu di Gunung Pentul dan rintisan Kampung Wisata Sejarah dan etnik di pedukuhan Kamal. Potensi industri kerajinan wilayah Karangsari ada kerajinan Parut di pedukuhan Dukuh, kerajinan Irus di pedukuhan Kopat, kerajinan fiber di padukuhan Kamal, serta potensi UMKM lainnya seperti olahan emping melinjau, emping pisang, anyaman bambo di padukuhan Suruhan dan Sendang. ${ }^{16}$ Sedangkan Potensi sosial berupa gotong royong, arisan, senam lansia maupun potensi seni budaya seperti Keroncong, jatilan, dan Teater Alugoro kesemua potensi masih melekat dan menjadi bagian dari indentitas warga Karangsari. Sementara dari sisi aset desa

\footnotetext{
14 Rencana Pembangunan Jangka Menengah Desa (RPJMDesa) 2019-2024, hlm.6

15 Rencana Pembangunan Jangka Menengah Desa (RPJMDesa) 2019-2024, hlm. 6

16 Data pontensi desa dan UKM 2017 dokumentasi Bumdes Binangun.
} 
sebagai sumber penghidupan, desa Karangsari hendak meraih kemajuan dan kemakmuran bersama dengan melibatkan seluruh pelaku pengembangan ekonomi desa baik pemerintah desa, swasta dan masyarakat melalui pergulatan dengan dimasukkan ketiga pelaku tersebut kedalam delapan indikator kunci meliputi (1) Indikator Kerangka Politik dalam desa; (2) Indikator Kelembagaan Desa; (3) Indikator Peluang pengembangannya; (4) Indikator Kultur Masyarakatnya, (5) Indikator Jaringan Kerjasama; (6) Indikator Sinkronisasi Global; (7) Indikator Penguasaan teknologi, dan; (8) Indikator Sosial yang Inklusi. ${ }^{17}$

Dalam pergulatan para pelaku pengembangan ekonomi desa tersebut kemudian diberikan peran masing-masing, dimana pemerintah desa mengambil peran dalam indikator: (1) Kerangka Politik yaitu kebijakan Kades dalam hal kebijakan membawa kondisi desa dalam masa pemerintahannya dibawa kearah mana kemajuan desa, dan (2) Kelembagaan Desa yang terlibat seperti LPMD dan lembaga kemasyarakatan desa lainnya. Sesuai dengan bidang LKD. Sedangkan dari pihak swasta dapat mengambil peran sebagai pelaku pengembangan ekonomi desa dalam indikator: (1) Mencari peluang pengembangan ekonomi desa dengan bekerjasama dengan pihak pemerintah desa dan masyarakat. (2) Pihak swasta dapat membantu pihak pemerintah desa dalam hal mencarikan jaringan atau membantu hal mengembangkan Jaringan pemerintah desa dalam mengembangkan ekonomi desa. (3) Pihak swasta juga berperan dalam hal sinkronisasi program desa dengan program pihak lain, serta (4) Pihak swasta juga berperan dalam penyediaan Teknologi bagi pengembangan ekonomi desa.

Sedangkan dari pihak masyarakat dapat mengambil peran sebagai pelaku pengembangan ekonomi desa dalam (1) menjaga kultur atau adat istiadat yang ada dalam kehidupan masyarakat desa, sebagai indentitas, bahwa kemajuan desa tidak boleh menghilangkan kultur khas desa. Dan (2) dalam pengembangan ekonomi desa harus berdasarkan pada sosial inklusi yaitu keterlibatan masyarakat dari berbagai macam lapisan, bahkan melibatkan kaum perempuan, kaum rentan

${ }^{17}$ Rencana Pembangunan Jangka Menengah Desa (RPJMDesa) 2019-2024. 
Partisipasi Perempuan Desa Karangsari...

maupun difabel sebagai aktor perubahan desa, sehingga tidak satupun warga masyarakat desa yang merasa ditinggalkan oleh pemerintah desa. ${ }^{18}$

\section{Aset Desa, Perempuan dan Kelompok Marjinal}

Dalam sebuah Workshop Membangun Visi Perubahan Pengelolaan Aset Desa yang Inklusif Desa Karangari diselenggarakan oleh Pemerintah Desa bersama Swara Nusa Institute (SNI) pada tanggal 18-20 Januari 2018 terdapat beberapa rumusan yang menjadi kesepakatan antara perwakilan dari perempuan, kelompok rentan dan difabel dengan pemerintah desa Karangsari. Beberapa rumusan kesepakatan tersebut adalah (1) Pemerintah desa akan menfasilitasi terbentuknya KKD (Kelompok Difabel Desa) Karangsari, (2) menganggarkan APBDesa untuk kegiatan pemberdayaan perempuan, kelompok rentan dan marjinal, (3) menerbitkan SK untuk keberadaan KDDK, dan (4) menfasilitasi sarana untuk kelompok rentan dan marjinal dengan menyedikan 1 (satu) kios desa untuk menampung kerajinan yang dihasilkan oleh kelompok difabel dan kaum rentan. ${ }^{19}$ Rumusan bersama ini merupakan momentum bagi perempuan desa, kelompok rentan dan marjinal untuk bersama-sama dengan pemerintah desa dalam pengelolaan dan pemanfaatan aset desa sebagai basis penghidupan berkelanjutan yang inklusif. Komitmen dari pemerintah desa ini merupakan bagian dari amanah UU Desa bahwa tidak ada satupun warga yang ditinggalkan dalam pembangunan dan pemberdayaan masyarakat. ${ }^{20}$

Apa yang menjadi komitmen bersama ini baik dari pemerintah desa, perempuan desa, dan warga kelompok rentan adalah menjadi tonggak sejarah baru di dalam tata kelola pengelolaan aset desa, dimana perempuan desa, kelompok rentan diberikan akses atas aset desa dan pengelolaannya untuk dijadikan sumber penghidupan berkelanjutan. Dalam upaya mewujudkan pengelolaan aset desa yang inklusif, diperlukan suatu langkah-langkah strategis terutama yang berkaitan

18 Rencana Pembangunan Jangka Menengah Desa (RPJMDesa) 2019-2024

19 Dokumentasi Swara Nusa Institute, Laporan Workshop Membangun Visi Perubahan Pengelolaan Aset Desa yang Inklusif di Desa Karangsari, 18-20 Januari 2018.

${ }^{20}$ Dokumentasi Swara Nusa Institute, Rekap proses "Pelatihan Aktor Perubahan: Program Tata Kelola Aset Desa Yang Inklusi”, Kulonprogo 13-15 Juli 2018. 
dengan pengelolaan aset desa agar bisa bermanfaat secara sosial dan ekonomi bagi warga desa terutama bagi perempuan, kelompok rentan dan marjinal.

Salah satu langkah strategis yang perlu dilakukan adalah melakukan analisa sosial atau pemetaan situasi dan kondisi sosial serta permasalahan sosial yang ada di desa sebagai dasar bagi sebuah perencanaan pengelolaan aset desa yang inklusif. ${ }^{21}$ Tanpa mengenali dan memahami situasi, kondisi dan permasalahan sosial yang ada di desa maka bisa dipastikan perencanaan desa yang terkait dengan pengelolaan aset desa tidak akan mampu menjawab permasalahan sosial yang ada di desa.

Berdasarkan hasil pemetaan situasi atau kondisi sosial terkait dengan kondisi perempuan desa, kelompok rentan dan marjinal mereka mengalami kerentanan disebabkan beberapa hal; pertama mereka kurang mendapatkan akses terhadap informasi, meskipun mereka tidak mempunyai aset berupa finansial, mereka mempunyai kemampuan berupa ketrampilan maupun keahlian namun belum terbuka dan diketahui, Menurut Iskandar Gunawan Direktur BUMDesa Binangun, banyak contoh warga yang hanya berpendidikan sampai Sekolah Dasar (SD) saja, dan mereka mempunyai kemampuan membuat produk bahkan bisa diekspor ke luar negeri. Namun kemampuan ini belum bisa dikelola dengan baik dan belum terbuka dan diketahui oleh orang banyak yang pada akhirnya masih berkutat ditingkat lokal saja.

Sebab Kedua, dalam hal pekerjaan kelompok rentan tidak mempunyai penghasilan tetap karena pekerjaan mereka bergantung pada proyek bagi buruh bangunan, maupun bergantung pada musim panen atau tanam bagi buruh tani. Mereka pada akhirnya tidak mendapatkan penghasilan yang pasti dikarenakan bergantung pada orang lain yang mempekerjakan mereka. Sebab ketiga, mereka mengalami kerentanan karena lemahnya Sumber Daya Manusia (SDM) dan tidak mempunyai ketrampilan yang bisa diandalkan. Menurut Kades Karangsari Mujirin, Kebanyakan kelompok rentan di desa ini pendidikan di bawah Sekolah Tingkat

${ }_{21}$ Tri Hariyono dan Iranda Yudhatama, Analisis Sosial dalam Pengelolaan Aset Desa yang Inklusi, (Kulonprogo: Swara Nusa Institute dan VOICE, 2018), hlm. 5-6 
Partisipasi Perempuan Desa Karangsari...

Atas (SLTA), tentu ada dampak dari globalisasi dan sebagainya, manusia butuh pengetahuan dan ketrampilan karena sebenarnya banyak kemampuan yang dimiliki mereka misalnya dikampung Gunung Pentul ada warga difable dan bekerja di percetakan batako dimana setiap harinya mampu mencetak batako lebih dari 200 buah, kalau itu diberi peningkatan kapasitas mereka akan mandiri. ${ }^{22}$

Sedangkan dalam pandangan pemerintah desa yang diidentifikasi kelompok rentan adalah keluarga miskin, difabel, perempuan rentan sosial ekonomi, dan lansia. Sedangkan kelompok penghayat tidak ada berdasarkan data agama saja, untuk LGBT belum ada datanya kemungkinan ada namun belum diinventarisir. Data Pemerintah Desa Karangsari menyebutkan bahwa Kelompok rentan ini masuk dalam kelompok Penyandang Masalah Kesejahteraan Sosial (PMKS) berjumlah 367 orang warga yang terbagi: (1) kelompok difabel 140 orang warga, (2) Perempuan Rawan Sosial Ekonomi 72 orang warga, keluarga Rumah Tidak Layak Huni 104 orang warga, dan (4) lansia 151 orang warga. ${ }^{23}$

Setelah dapat ditemukan siapa, apa kelompok rentan dan marjinal di desa Karangsari berikut dengan permasalahan utama yang dihadapi, langkah selanjutnya adalah melakukan pemetaan terhadap para pihak (stake bolder) desa yang terkait dengan pengelolaan aset desa seperti, pemerintah desa, BUMDes, dan kelompok rentan. ${ }^{24}$

Berdasarkan hasil pemetaan situasi para pihak desa mensepakati untuk: Pertama, pihak Pemerintah desa menfasilitasi terbentuknya kelompok difabel desa, dengan melakukan aktivitas: (a) pendataan kelompok difabel dan perempuan miskin yang melibatkan jurnalisme karang taruna dan kader sosial desa, (b) pertemuan pembentukan forum KDDK (Kelompok Difabel Desa Karangsari), dan menfasilitasi pertemuan rutin kelompok difabel dan perempuan miskin; (c) Menganggarkan APBDesa, aktivitas yang dilakukan terkait dengan tahapan ini adalah Pemdes menerbitkan SK Forum KDDK, dan menganggarkan kegiatan pelatihan dan studi banding untuk Forum KDDK; (d) Peningkatan kapasitas

${ }^{22}$ Laporan Assesment, "Problem-Problem Tata Kelola Aset Desa yang Inklusif”, hlm.3-4

${ }^{23}$ Data diperoleh dari ibu Saptariningsih Kasie Kemasyarakatan Desa Karangsari 2017.

${ }^{24}$ Tri Hariyono dan Iranda Yudhatama, Analisis Sosial dalam Pengelolaan Aset, hlm.6 
Pemdes, aktivitasnya adalah pendes yang terdiri dari 25 perangkat desa terlibat dalam pelatihan tentang hak-hak kaum difabel dan kelompok rentan; (e) Program pendidikan dan pelatihan untuk kelompok rentan; (f) Menfasilitasi sarana kios untuk kelompok difabel dan perempuan miskin, yaitu pembes menfasilitasi 1 kios desa yang nantinya digunakan untuk menampung hasil usaha ekonomi kreatif tersebut.

Kedua, dalam hal kelembagaan ekonomi (BUMDesa) Karangsari melakukan; (a) Program pelatihan untuk peningkatan kapasitas BUMDesa, dengan melakukan aktivitas pelatihan pengelolaan aset desa yang inklusi dan pelatihan bisnis plan, pesertanya adalah direksi dan karyawan BUMDesa; (b) BUMDesa menfasilitasi pemasaran usaha kelompok difabel dan perempuan miskin dengan membuat branding hasil usaha kelompok tersebut dengan target agar penamaan produk serta bisnis plan. Sedangkan pihak perempuan dan kelompok rentan, dengan melakukan : (a) Pendataan kondisi dan kebutuhan kelompok rentan dan perempuan miskin, dengan aktivitas melakukan pendataan kelompok difabel desa karangsari dan perempuan miskin; (b) Peningkatan kapasitas berupa pendidikan dan pelatihan; (c) Pembentukan organisasi/kelompok difabel desa dan unit usaha kelompok dengan target dibulan februari akhir sudah terbentuk forum KDDK dan unit usaha ekonomi kratif; (d) Penguatan organisasi dengan melakukan pertemuan rutin Forum KDDK dilakukan setiap 2 (dua) bulan sekali, serta mengelola unit usaha bersama. ${ }^{25}$

Apa yang menjadi kesepatan bersama antar para pihak tersebut merupakan suatu langkah yang positif menuju pada pengelolaan aset desa yang Inklusi (PADI). Inisiasi program PADI di desa Karangsari tersebut menghasilkan beberapa hal sebagai berikut:

1. Munculnya kesadaran dari kelompok rentan dan marjinal akan arti pentingnya memperjuangkan kepentingan mereka melalui wadah organisasi di tingkat desa;

25 Dokumentasi Swara Nusa Institute, Laporan Workshop Membangun Visi Perubahan Pengelolaan Aset Desa yang Inklusif di Desa Karangsari, 18-20 Januari 2018. 
2. Terbentuknya Kelompok Difabel Desa (KDD) Karangsari yang difasilitasi oleh Pemerintah Desa Karangsari dan Swara Nusa Institute serta diakuinya KDD sebagai lembaga kemasyarakatan desa (LKD);

3. Kelompok Difabel Desa, Kelompok Perempuan Tani, dan pemuda berpartisipasi aktif dalam Musyawarah Desa dan mulai mengartikulasikan kepentingannya dalam forum tersebut;

4. Pemerintah desa Karangsari mengalokasikan anggaran untuk pemberdayaan difabel dan Kelompok Tani Perempuan dalam bentuk pendidikan dan pelatihan dalam APBDes;

5. BUMDesa Karangsari membantu memasarkan produk-produk hasil olahan kelompok difabel dan kelompok tani perempuan;

6. Meningkatknya pendapatan kelompok rentan dan marjinal desa. ${ }^{26}$

\section{Pengembangan Ekonomi Lokal Bagi Perempuan Desa}

Undang-Undang No. 6 Tahun 2014 tentang Desa secara substansi telah mengamanatkan bahwa peran aktif atau partispasi masyarakat dan responsivitas pemerintahan desa dalam pengelolaan pemerintahan dan pembangunan adalah faktor kunci keberhasilan pembangunan di desa dengan mendayagunakan segala potensi dan aset yang ada di desa seperti sumber daya manusia, sumber daya alam, dan potensi ekonomi untuk meningkatkan kesejahteraan masyarakat desa atau dengan kata lain aset desa yang ada dapat dikelola dan dirasakan manfaatnya secara inklusif. Pada intinya pengelolaan aset desa yang inklusif adalah terwujudnya tata kelola aset desa yang memberikan ruang bagi setiap orang warga desa terutama kelompok rentan dan marjinal terlibat dalam proses pengambilan keputusan dan tidak ada hambatan apapun bagi mereka untuk mengakses serta mengontrol sumberdaya yang ada untuk memenuhi kebutuhan dasar yang layak. ${ }^{27}$

26 Iranda Yudhatama, Tri Hariyono dan Porcarius Mahi, "Mengatasi Kemiskinan dan Ketimpangan Melalui Pengelolaan Aset Desa yang Inklusi (PADI)", Policy Brief SNI 2019, hlm.3

27 Terdapat tiga ruang inklusi sosial dalam penyelenggaraan pemerintah dan pembangunan desa, didasarkan pada sasaran kelompok marjinal. Bentuk pertama berupa pengakuan atas masyarakat hukum adat untuk menyelenggarakan pemerintahan yang didasarkan pada hak asal-usul dan susunan asli (subsidiaritas). Pengakuan tersebut memberi kesempatan pada masyarakat hukum adat untuk berpartisipasi dalam pembangunan dan penyelenggaraan pemerintahan secara umum. Bentuk kedua inklusi sosial dalam UU Desa berupa pemberian kesempatan kepada kelompok miskin dan 
Sebagaimana yang dijelaskan sebelumnya, bahwa desa Karangsari hendak meraih kemajuan dan kemakmuran bersama dengan melibatkan seluruh pelaku pengembangan ekonomi desa baik pemerintah desa, swasta dan masyarakat melalui delapan indikator kunci dimana para pelaku pengembangan ekonomi desa tersebut kemudian diberikan peran masing-masing, tidak ketinggalan perempuan desa, kelompok rentan dan marjinal yang merupakan bagian dari warga masyarakat desa bahu-membahu ikut terlibat dan mengorganisasikan diri sebagai salah satu strategi nafkah dalam rangka mengembangkan penghidupan berkelanjutan. Keterlibatan mereka dalam pengelolaan aset desa nampak terlihat dalam tiga sektor area yaitu sektor pertanian, UMKM, dan Pariwisata.

Di sektor pertanian ini, perempuan desa, kelompok rentan dan marjinal terwadahi dalam Kelompok Wanita Tani (KWT) Sendang Rejeki dipadukuhan Sendang, dan KWT Lestari di Padukuhan Kamal. Di KWT Sendang ini disediakan aset tanah pelungguh dari kepala dukuh Sendang, seluruh anggota yang sebagian besar adalah kelompok rentan di padukuhan Sendang bersama-sama mengelola lahan tersebut secara kolektif. Lahan kolektif ditanami sayur-sayuran dan hasilnya dipasarkan melalui pasar desa dan sebagian lainnya dipasarkan secara langsung kepada konsumen (warga padukuhan sendang) dan sekitarnya. Disamping itu juga anggota KWT dengan memanfaatkan pekarangan yang ada dirumahnya mengelola dan menanam sayuran dengan sistem polybag. Hal ini untuk memenuhi kebutuhan pangan sehari-hari.

Keberadaan KWT Sendang Rejeki ini juga mendapatkan perhatian dari BPPT Kecamatan pengasih, dimana anggota KW'T diberikan bantuan berupa ternak ayam dengan skema bantuan KUBE (Kelompok usaha bersama) dan bantuan ayam ini bisa dikembangkan dalam artian berkelanjutan melalui telur yang dihasilkan oleh induk ayam kube ini. Dan kegiatan ini menurut Ibu Purwati, salah

perempuan untuk berpartisipasi dalam perencanaan dan penyelenggaraan desa, serta pembangunan desa. Sedangkan bentuk ketiga inklusi sosial dialamatkan kepada semua warga desa, termasuk kelompok marjinal, untuk berpartisipasi dalam penataan desa, perencanaan desa, penyelenggaraan pemerintahan dan pembangunan desa. Lebih lanjut lihat Ricardo Simarmata dan R. Yando Zakaria, "Perspektif Inklusi Sosial dalam UU Nomor 6 Tahun 2014 tentang Desa: Kebijakan dan Tantangan Implementasi”, Jurnal Wacana: Meretas Jejak Kesejabteraan Desa. Nomor 37/Tahun XIX/2017, hlm.10 
Partisipasi Perempuan Desa Karangsari...

satu anggota KWT dan juga merupakan aktor perubahan desa Karangsari menuturkan bahwa; "kita diberi bantuan itu untuk mencukupi kebutuhan gizi warga dan meningkatkan ekonomi juga mempunyai tujuan supaya desa mandiri pangan itu bisa terwujud di Karangsari dimana pelopornya adalah ibu$\mathrm{ibu/kelompok} \mathrm{perempuan} \mathrm{termasuk} \mathrm{didalamnya} \mathrm{ada} \mathrm{kelompok} \mathrm{rentan} \mathrm{seperti}$ kami ini". ${ }^{28}$

Apa yang dilakukan oleh KWT Sendang Rejeki ini merupakan salah satu bagian dari bagaimana aset desa bisa dimanfaatkan sebagai basis penghidupan ekonomi yang berkelanjutan dengan pengembangan tanaman pangan dan juga produksi ayam serta telur. Hal ini berarti telah menggunakan aset desa yang dimiliki oleh masyarakat dengan membentuk perkumpulan ekonomi kolektif dengan tujuan untuk memenuhi kebutuhan pangan sehat dan peningkatan ekonomi kelompok melalui pengembangan dan pengelolaan kebun kolektif tersebut dengan harapan agar desa mandiri pangan di desa Karangsari segera tercapai dan kesejahteraan serta peningkatan ekonomi warga desa terutama kelompok rentan yang terlibat dalam kegiatan KWT Sendang Lestari terangkat penghidupan ekonominya.

Adapun KWT Lestari padukuhan Kamal yang sebagian anggotanya juga warga kelompok rentan, didalamnya adalah petani miskin dan buruh tani perempuan dimana keberadaanya di desa Karangsari ini masih banyak dijumpai. Melalui kegiatan bersama yang dihimpun oleh kelompok perempuan secara kolektif ini bersama-sama mengelola dan mengembangkan kebun TOGA (Tanaman obat Keluarga), dipekarangannya mereka menanami jenis emponempon, jahe, dan sebagainya untuk dijadikan bahan olahan Jamu dan minuman sehat. Disamping itu juga dengan bantuan dari BPP Kecamatan Pengasih, juga mendapatkan bantuan berupa penggemukan kambing dengan skema KUBE, tujuan dari kegiatan adalah untuk memanfaatkan waktu luang petani perempuan

28 Dokumentasi Swara Nusa, Diskusi Komunitas seri ke-5, KWT Sendang Rejeki: Menuju Tata Kelola Aset Desa yang Inklusi, 26 Nopember 2018. 
ketika tidak pergi ke ladang tetangga untuk buruh tandur (menam padi), matun (menyiangi gulma di sawah pada tanaman padi), dan panen ketika musim padi. ${ }^{29}$ Sedangkan akses yang diberikan oleh pemerintah desa dalam kerangka mendukung kegiatan ekonomi pertanian sebagai basis penghidupan berkelanjutan untuk KWT Sendang difasilitasi pendidikan ketrampilan dengan pengelolaan dan manajeman pemasaran, disamping itu juga untuk ketersediaan air dalam memehuhi kebutuhan produksi sayuran difasilitasi sarana air untuk pengairan dan penyiraman tanaman. Sedangkan untuk KWT Lestari pemerintah desa memberikan dukungan berupa pelatihan untuk pasca penen yaitu proses kemasan produk dan pemberian bantuan alat untuk memproduksi Jamu yang dihasilkan dari Tanaman obat keluarga (TOGA) bersama kelompok KWT Lestari. Disamping itu juga KWT Lestari bersama dengan UPT Dinas pertanian Kecamatan Pengasih merancang untuk kegiatan pangan lokal yang inklusif.

Di sektor Usaha Mikro Kecil dan Menengah (UMKM) bersama dengan BUMDesa Binangun melakukan pemetaan terkait dengan keberadaan UMKM yang ada di desa Karangsari. Hasil pemetaan tersebut kemudian menjadi dasar bagi BUMDesa untuk melakukan berbagai kegiatan terkait dengan pemasaran produk dan juga pelatihan menejemen serta kapasitas bagi pelaku UMKM. Selain itu difasilitasi berupa Lapak untuk berjualan di area pasar tiban (Pasar Inovasi Desa) di Gua Batu Jonggol yang berada dipadukuhan Gunung Pentul. BUMDesa menyelenggarakan Pasar Inovasi desa disetiap bulan di hari Minggu Kliwon. Warga desa Karangsari terutama di daerah wisata tersebut diberikan akses lokasi untuk berjualan hasil UMKM mereka. Berkaitan dengan akses untuk para pelaku UMKM ini menurut Bapak Iskandar Selaku Direktur BUMDesa menjelaskan; "Pasar Inovasi Desa (Pasar Sor So) yang dilakukan setiap minggu kliwon terdapat sekitar 25 UKM yang terlibat, dibulan Maret 2018 sampai hari ini sudah bertambah menjadi 50 UKM yang ikut berjualan dipasar tersebut dengan demikian memberikan income tambahan bagi para UKM, dan ini menjadi berita gembira bagi

${ }^{29}$ Dokumentasi Swara Nusa Institute, Diskusi Komunitas ke-3 KWT Lestari, Desa Mandiri Pangan yang Inklusif, 10 Oktober 2018 
Partisipasi Perempuan Desa Karangsari...

BUMDesa karena kegiatan tersebut mendapat antusiasme yang tinggi dari warga Karangsari”, ${ }^{30}$

Dengan demikian, warga masyarakat juga merasakan kemanfaatan terkait dengan kegiatan Pasar Inovasi Desa tersebut, dengan memberikan kontribusi ekonomi bagi warga masyarakat terutama kelompok rentan desa. Kehadiran para perempuan desa ikut berpatisipasi dalam pembangunan desa di bidang wirausaha dan memiliki jiwa kepedulian terhadap sesama sangat diharapkan untuk dapat memberdayakan potensi-potensi yang dimiliki masyarakat desa pada skala sosial ekonomi. Harapannya adalah memberikan jalan keluar agar dapat menguraikan dan mereduksi kemiskinan yang tengah dihadapi masyarakat saat ini. ${ }^{31}$

Di sektor Pariwisata bersama dengan Pokdarwis mengelola paket wisata desa, misalnya di wisata alam Tangkil Kliff yang berada di padukuhan Kedungtangkil, wisata kedung Gender Josutan dan wisata alam dan perkemahan di padukuhan kamal serta wisata goa batu Jonggol dipadukuhan Gunung pentul, warga masyarakat desa dan juga kelompok rentan diikutkan dalam pengelolaan wisata tersebut. Sedangkan kontribusi pemerindah desa dengan memberikan dukungan berupa bantuan sarana dan prasarana penunjang wisata seperti sarana air bersih dan penyediaan Kamar mandi dan toilet. Dari pemdes hanya meminta bagi hasil retribusi masuk wisata saja, sedangkan untuk retribusi lainnya dikelola oleh pokdarwis dan juga warga setempat. Inilah beberapa aset desa yang pengelolaannya melibatkan perempuan desa, kelompok rentan dan marjinal. Mereka diberikan akses, serta kontrol dalam pengelolaan aset desa dengan didukung oleh kelembagaan ekonomi desa (BUMDesa) dengan tujuan untuk mereka menjadi mandiri melalui pengelolaan aset desa yang inklusif.

\section{E. Penutup}

Bahasan di atas menunjukkan bahwa aset desa memiliki peran signifikan dalam menopang dan menggerakkan sumber penghidupan warga. Pemetaan aset

\footnotetext{
30 Dokumentasi Swara Nusa, Hasil Kunjungan Lapangan BUMDesa Karangsari, tanggal 06 Maret 2018.

31 Linda Indriyarti Putri, "Reduksi Kemiskinan Melalui Sociopreneurship", dalam Islamic Review: Jurnal Riset dan Kajian Keislaman, Vol. VI No.2 Tahun 2017, hlm. 48
} 
desa menjadi penting untuk menjadi instrumen perluasan sumber penghidupan warga dan desa. Perlu menjadi catatan adalah ketika melakukan pemetaan aset desa, sebaiknya juga menyinggung soal faktor kepemilikan dan akses terhadap aset desa tersebut. Hal ini terutama untuk memastikan bahwa perempuan dan kelompok marjinal di desa juga memiliki kesempatan yang sama dalam memanfaatkan aset desa. Lebih dari itu, dinamika ekonomi perempuan desa, sebagaimana kasus desa Karangari, memerlukan tidak hanya dukungan kelembagaan, seperti pengorganisasian kelompok dan bekal keterampilan, tetapi juga diperlukan dukungan akses pemasaran yang mengintegrasikan ekonomi lokal desa ke dalam pasar produk usaha mikro, kecil, dan menengah (UMKM) integrasi usaha warga ke dalam lembaga desa semacam BUMDesa tentu akan memberikan keuntungan lebih besar kepada pemerintah desa.

Beberapa agenda yang bisa dilakukan studi lanjut terhadap tulisan ini adalah diantaranya (1) penting mendalami regulasi pemerintah kabupaten maupun desa untuk mengalokasikan APBD maupun APBDesa yang diperuntukan bagi pengembangan ekonomi desa yang inklusif. (2) Mengoptimalkan peran BUMDesa sebagai institusi ekonomi desa yang mampu meningkatkan PADesa dan kemanfaatan bagi kelompok rentan melalui pengelolaan potensi dan asset desa secara inovatif.

\section{Daftar Pustaka}

Chambers, R., \& Conway, G. Sustainable rural livelihoods: practical concepts for the 21st century. Institute of Development Studies (UK), 1992.

Eko, Sutoro, dkk, Mutiara Perubahan: Inovasi dan Emansipasi Desa dari Indonesia Timur, Yogyakarta: IRE dan ACCESS Phase II, 2013. , et.al. Desa Membangun Indonesia, Yogyakarta: FPPD, 2014.

Fakih, Mansour, Runtubnya Teori Pembangunan dan Globalisasi, Yogyakarta: Pustaka Pelajar dan Insist Press, 2001.

Hariyono, Tri, dan Iranda Yudhatama, Analisis Sosial dalam Pengelolaan Aset Desa yang Inklusi, Kulonprogo, Swara Nusa Institute dan VOICE, 2018. 
Partisipasi Perempuan Desa Karangsari...

Khoiriyah, Nur, "Pandangan Sosial Ekonomi dan Keagamaan Masyarakat Petani Di Jawa", dalam Islamic Review: Jurnal Riset dan Kajian Keislaman, Vol. VI No.2 Tahun 2017.

Langer, Carol L. dan Cynthia A. Lietz, Applying Theory to Generalist Social Work Practice: A Case Study Approach, Canada: Wiley, 2015.

Laporan Assesment, "Problem-Problem Tata Kelola Aset Desa yang Inklusif dan Memihak Kaum Rentan di Desa Karangsari Kulonprogo", Kulonprogo: Swara Nusa Institute, 2017.

Nugroho, Riant, Kebijakan Sosial untuk Negara Berkembang, Yogyakarta: Pustaka Pelajar, 2014.

Prasetyantoko A., Sugeng Bahagiyo, dan Setyo Budiantoro, Prolog "Prospek dan Tantangan Pembangunan Inklusi di Indonesia", dalam A Prasetyantoko, Sugeng Bahagiyo, dan Setyo Budiantoro ed. Pembangunan Inklusif: Prospek dan Tantangan Indonesia, Jakarta: LP3ES dan Prakarsa, 2012.

Putri, Linda Indriyarti, "Reduksi Kemiskinan Melalui Sociopreneurship", dalam Islamic Review: Jurnal Riset dan Kajian Keislaman, Vol. VI No.2 Tahun 2017

Sasono, Adi, Menjadi Tuan Di Negeri Sendiri: Pergulatan Kerakyatan, Kemartabatan, dan Kemandirian, Jakarta: Grafindo Books Media, 2013.

Simarmata dan R. Yando Zakaria, "Perspektif Inklusi Sosial dalam UU Nomor 6 Tahun 2014 tentang Desa: Kebijakan dan Tantangan Implementasi”, Jurnal Wacana: Meretas Jejak Kesejahteraan Desa. Nomor 37/Tahun XIX/2017

Soetomo, Masalah Sosial, Pembangunan Sosial dan Kesejabteraan, Yogyakarta: Pustaka Pelajar, 2018.

Swara Nusa Institute, Laporan Workshop Membangun Visi Perubahan Pengelolaan Aset Desa yang Inklusif di Desa Karangsari, 18-20 Januari 2018.

Diskusi Komunitas ke-3 KWT Lestari, Desa Mandiri Pangan yang Inklusif, 10 Oktober 2018

Diskusi Komunitas seri ke-5, KWT Sendang Rejeki: Menuju Tata Kelola Aset Desa yang Inklusi, 26 Nopember 2018.

, Rekam proses "Pelatihan Aktor Perubahan: Program Tata Kelola Aset Desa Yang Inklusi”, Kulonprogo 13-15 Juli 2018.

Yudhatama, Iranda, Tri Hariyono dan Porcarius Mahi, "Mengatasi Kemiskinan dan Ketimpangan Melalui Pengelolaan Aset Desa yang Inklusi (PADI)", Policy Brief SNI 2019 